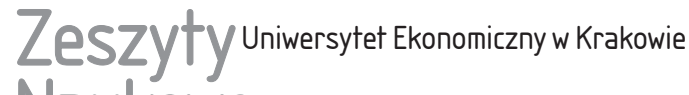 Naukowe
}

$10(934)$

ISSN 1898-6447

Zesz. Nauk. UEK, 2014; 10 (934): 107-122

DOI: 10.15678/ZNUEK.2014.0934.1008

Katarzyna Mikołajczyk

Katedra Finansów

Uniwersytet Ekonomiczny w Krakowie

\section{Czynniki kształtujące kredyty bankowe dla przedsiębiorstw w krajach Europy Środkowo- -Wschodniej}

\section{Streszczenie}

W okresie przedkryzysowym banki w krajach Europy Środkowo-Wschodniej, w dużym stopniu dzięki finansowemu wsparciu kontrolujących ich banków, gwałtownie zwiększyły wartość udzielanych kredytów, szczególnie kredytów konsumpcyjnych i mieszkaniowych. Dynamika kredytów osiągała w niektórych krajach zawrotne tempo sięgające nawet $50 \%$ w skali roku, równocześnie jednak udział kredytów dla przedsiębiorstw w strukturze kredytów ogółem zmniejszał się, przykładowo w Polsce do poziomu ok. 30\%. Celem artykułu jest analiza porównawcza tendencji w zakresie kredytowania przedsiębiorstw w krajach Europy Środkowo-Wschodniej oraz próba identyfikacji czynników, które wpłynęły na ich zróżnicowanie. Na podstawie jednostkowych danych finansowych banków dokonano weryfikacji hipotezy badawczej, że źródłem zróżnicowania były w większym stopniu czynniki makroekonomiczne w kraju goszczącym niż strategia przyjęta na poziomie międzynarodowych grup bankowych.

Słowa kluczowe: finansowanie przedsiębiorstw, kredyty bankowe, struktura kredytów, Europa Środkowo-Wschodnia. 


\section{Wprowadzenie}

Kluczową funkcją, jaką pełnią banki w gospodarce, jest dostarczanie kredytu podmiotom sektora niefinansowego, zarówno przedsiębiorstwom, jak i gospodarstwom domowym. Współczesna gospodarka w coraz większym stopniu finansuje bieżące wydatki długiem, czego efektem jest wzrastający poziom zadłużenia. Stosunek długu sektora prywatnego do PKB w większości krajów rozwiniętych przekracza 200\%, a w niektórych nawet $400 \%$ (np. Irlandia, Luksemburg). Sektor prywatny w krajach Europy Środkowo-Wschodniej (CEE) jest relatywnie mniej zadłużony, poziom ten jednak stale rośnie ${ }^{1}$. Analizując problem zadłużenia i jego skutki dla gospodarki narodowej, trzeba jednak uwzględnić nie tylko poziom długu, ale też jego strukturę oraz przeznaczenie. Dla przedsiębiorstw kapitał obcy jest niezbędnym źródłem finansowania działalności inwestycyjnej, umożliwiającym dynamiczny rozwój i pozwalającym wykorzystać efekt dźwigni finansowej do zwiększenia rentowności kapitału własnego. Gospodarstwa domowe wykorzystują dług głównie do finansowania wydatków konsumpcyjnych oraz mieszkaniowych. Z perspektywy makroekonomicznej zwiększenie możliwości finansowych obydwu grup podmiotów jest czynnikiem sprzyjającym wzrostowi gospodarczemu, pod warunkiem jednak że koszty obsługi długu nie stanowią zbyt dużego obciążenia, które mogłoby doprowadzić do utraty wypłacalności. Trudno wyznaczyć bezpieczną granicę zadłużenia, chociaż w literaturze przedmiotu można znaleźć próby jej oszacowania. S.G. Cecchetti, M.S. Mohanty i F. Zampoli [2011], opierając się na danych dotyczących krajów OECD, ustalili, że poziom długu przedsiębiorstw przekraczający $90 \%$ PKB, a długu gospodarstw domowych przekraczający $85 \%$ PKB stanowi na tyle silne obciążenie finansowe, że staje się czynnikiem hamującym wzrost gospodarczy kraju. W sytuacji gdy podaż kapitału jest ograniczona, niezwykle istotne jest jednak, aby zapewnić finansowanie działalności przedsiębiorstw i aby rywalizacja o kredyt z sektorem gospodarstw domowych nie tworzyła dla nich dodatkowych przeszkód w dostępie do kapitału. Przedsiębiorstwa mogą finansować inwestycje także z niebankowych, zewnętrznych źródeł kapitału, duże i dojrzałe przez emisję papierów wartościowych, a mniejsze lub będące w początkowej fazie swojego rozwoju przez fundusze venture capital / private equity, ale dostępność kredytów bankowych, szczególnie w mniej zaawansowanym finansowo regionie CEE, jest bardzo istotna.

Z perspektywy banku hierarchia celów może być jednak inna. Kredyty konsumpcyjne należą do najwyżej oprocentowanych kredytów, a kredyty mieszkaniowe

${ }^{1}$ W 2000 r. średni poziom zadłużenia sektora prywatnego w stosunku do PKB w krajach Europy Środkowej (Polska, Czechy, Słowacja, Słowenia, Węgry) wynosił 114\%, a w 2011 r. przekroczył 155\%. Najbardziej zadłużonym krajem były Węgry (220\%), a najmniej zadłużonym Słowacja (114\%); http://stats.oecd.org (dostęp: 18.05.2014). 
zapewniają wieloletnie przychody, charakteryzując się przy tym relatywnie niskim poziomem ryzyka. Dla banku mniej atrakcyjne może być zatem kredytowanie działalności gospodarczej, szczególnie w sektorze MŚP, w którym jakość należności kredytowych jest najniższa, wymaga większego zaangażowania w celu właściwej oceny zdolności kredytowej i monitoringu. Na strukturę kredytów duży wpływ ma także wielkość banku, jego struktura własnościowa oraz przyjęty model biznesowy [De Haas, Ferreira i Taci 2010]. Z punktu widzenia gospodarki ważne jest jednak, aby zachować właściwe proporcje w podmiotowej strukturze udzielonych kredytów, aby zwiększony popyt na kredyty niegospodarcze nie ograniczał finansowania dostępnego dla przedsiębiorstw. Jak bowiem podkreślają T. Beck i in. [2012], to właśnie wzrost kredytów dla przedsiębiorstw jest czynnikiem sprzyjającym wzrostowi gospodarczemu, podczas gdy relacja pomiędzy wzrostem kredytów dla gospodarstw domowych i wzrostem gospodarczym jest znacznie mniej istotna.

Celem artykułu jest analiza porównawcza tendencji w zakresie kredytowania przedsiębiorstw w krajach Europy Środkowo-Wschodniej oraz próba identyfikacji czynników, które wpłynęły na ich zróżnicowanie. Do wstępnej analizy wykorzystano dane dotyczące wszystkich krajów Unii Europejskiej, które podzielono na kilka podgrup podmiotowych. W dalszej części szczególną uwagę skoncentrowano na danych dotyczących siedmiu krajów, które przeanalizowano dla trzech okresów: boomu kredytowego (marzec 2004 - marzec 2008), kryzysu finansowego (marzec 2008 - marzec 2011) oraz okresu pokryzysowego (marzec 2011 - marzec 2014). W części empirycznej na podstawie jednostkowych danych finansowych banków, korzystając z modelu regresji, dokonano weryfikacji hipotezy badawczej, mówiącej, że źródłem zróżnicowania były w większym stopniu czynniki makroekonomiczne w kraju goszczącym niż strategia przyjęta na poziomie międzynarodowych grup bankowych.

\section{Struktura kredytów bankowych w krajach Unii Europejskiej}

Rozszerzenie Unii Europejskiej o dziesięciu nowych członków w 2004 r. (i dwóch kolejnych w 2006 r.) wyraźnie nasiliło wewnętrzne zróżnicowanie pomiędzy krajami członkowskimi. Na potrzeby dalszej analizy wyróżniono zatem pięć grup podmiotowych: kraje tzw. starej Unii (EU-15), kraje Europy Środkowej (CE-5: Polska, Słowacja, Czechy, Węgry i Słowenia), kraje Europy Południowo-Wschodniej (SE-2: Bułgaria i Rumunia), kraje nadbałtyckie (BAL-3: Litwa, Łotwa i Estonia) oraz nowi członkowie UE nienależący do regionu Europy przechodzącego transformację (NT-2: Malta i Cypr). Grupy te wykazywały silne zróżnicowanie pod względem poziomu nasycenia gospodarki kredytami bankowymi, co wpłynęło na zróżnicowanie struktury i dynamiki rozwoju akcji kredytowej (rys. 1). 


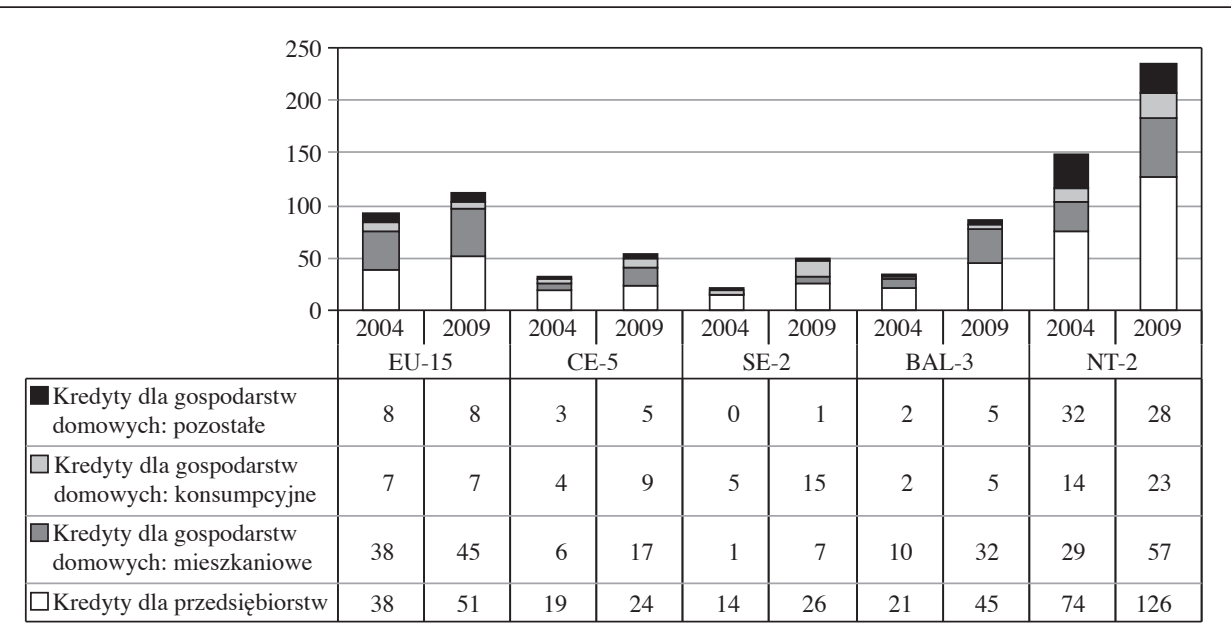

Rys. 1. Kredyty bankowe w relacji do PKB (w \%)

Źródło: obliczenia własne na podstawie: [EU Banking Structures... 2010].

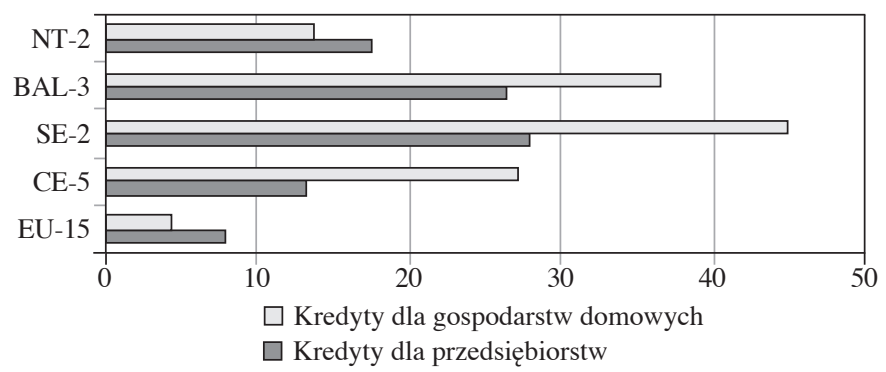

Rys. 2. Średnia roczna stopa wzrostu kredytów w latach 2004-2009 w wyróżnionych grupach (w \%)

Źródło: obliczenia własne na podstawie: [EU Banking Structures... 2010].

W 2004 r. wartość kredytów bankowych udzielonych w krajach EU-15 stanowiła 92\% ich łącznego PKB, z czego kredyty udzielone przedsiębiorstwom niefinansowym stanowiły $38 \%$ PKB, a kredyty udzielone gospodarstwom domowym kolejne 54\%. Nasycenie kredytami bankowymi w regionie CEE było w 2004 r. niemal trzykrotnie niższe: w krajach SE-2 wynosiło zaledwie $21 \%$ PKB, a w krajach CE-5 i BAL-3 ok. 33\%. Szczególnie duża luka istniała w segmencie kredytów mieszkaniowych, tylko częściowo zmniejszona w okresie kolejnych lat. Wyraźnie odróżniały się na tle wszystkich grup Cypr i Malta: w grupie NT-2 już w roku akcesji kredyty sięgały $150 \%$ PKB, a w ciągu najbliższych 5 lat wzrosły do poziomu $234 \%$. 
Odmienna była także struktura kredytów. W krajach EU-15 kredyty dla gospodarstw domowych stanowiły w 2004 r. ok. $60 \%$ kredytów ogółem dla sektora niefinansowego, podczas gdy w krajach CEE udział ten wynosił ok. 40\%. Jak wskazują T. Beck i in. [2012], w krajach silniej rozwiniętych ekonomicznie znaczenie kredytów gospodarczych jest relatywnie większe niż kredytów niegospodarczych, a wraz rozwojem sektora bankowego udział kredytów dla gospodarstw domowych wzrasta. W ciągu kolejnych 5 lat średnia roczna stopa wzrostu (compound annual growth rate - CAGR) kredytów dla gospodarstw domowych wyniosła w krajach EU-15 ok. 4\%, podczas gdy w krajach CE-5 27\%, BAL-3 36\%, a w krajach SE-2 nawet $45 \%$ (rys. 2).

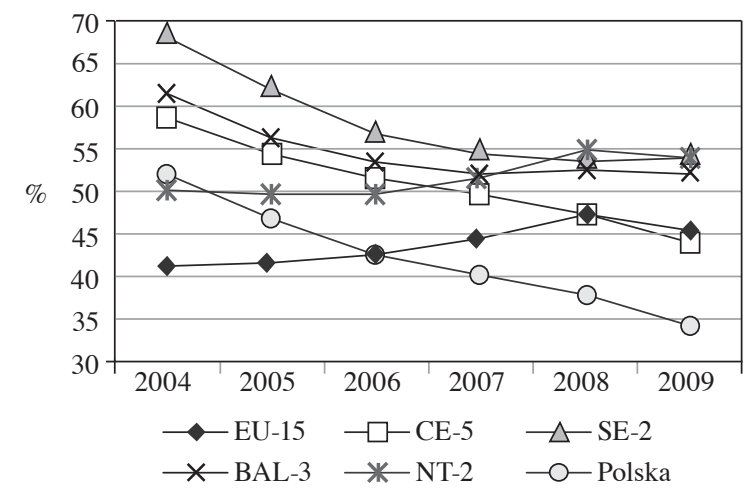

a) udział w kredytach ogółem dla sektora niefinansowego

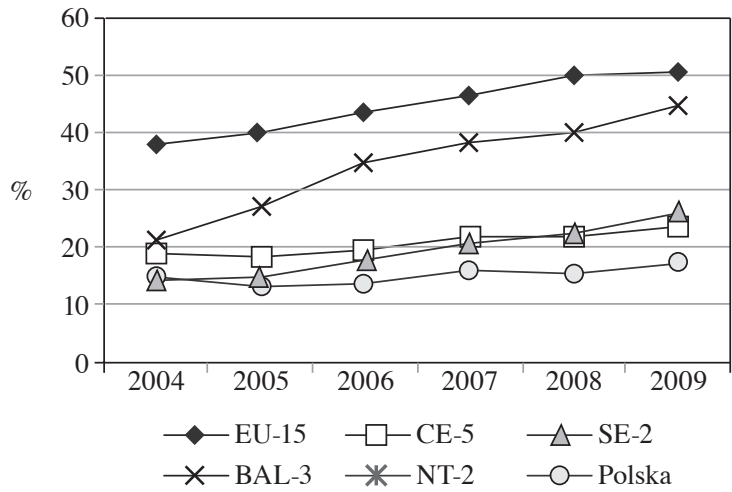

b) w relacji do $\mathrm{PKB}$

Uwaga: kraje NT-2 ze względu na wysoki poziom wskaźnika (wzrost z 74\% do 126\%) nie zostały ujęte na wykresie.

Rys. 3. Kredyty dla przedsiębiorstw niefinansowych

Źródło: [EU Banking Structures... 2010]. 


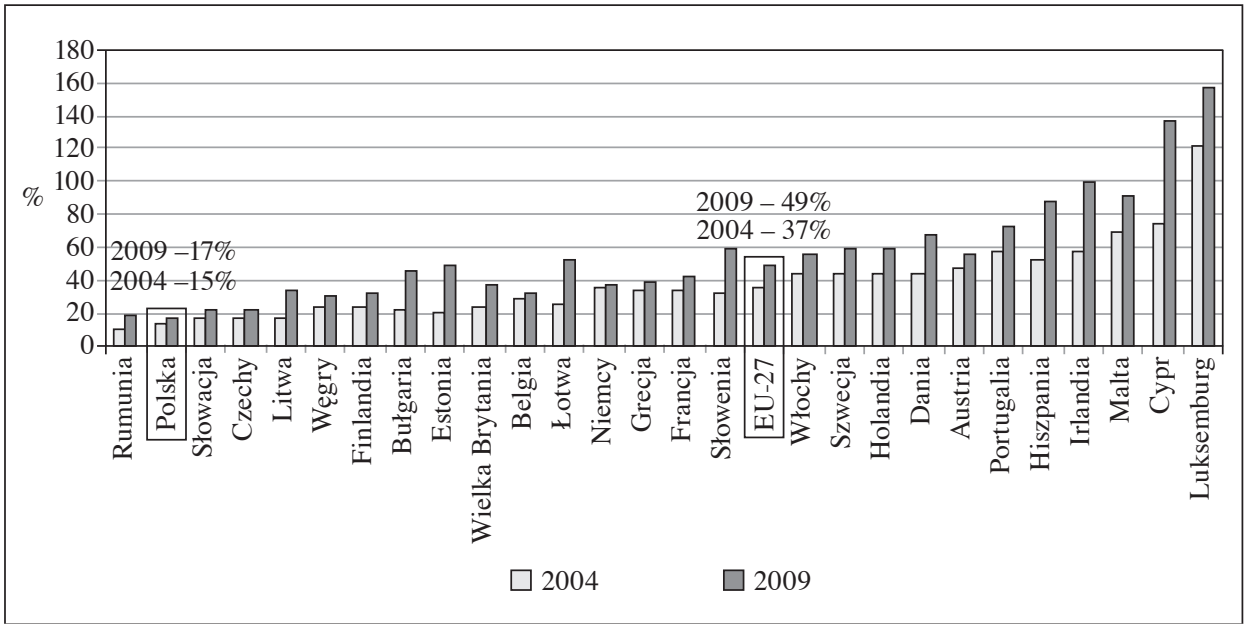

Rys. 4. Zróżnicowanie relacji wartości kredytów bankowych dla przedsiębiorstw do PKB (w cenach rynkowych) w krajach UE (w \%)

Źródło: [EU Banking Structures... 2010].

Gwałtowny przyrost kredytów w regionie CEE odbywał się głównie w segmencie kredytów niegospodarczych. W efekcie w 2009 r. poziom kredytów konsumpcyjnych w relacji do PKB w krajach CE-5, a szczególnie w krajach SE-2, był wyższy niż w krajach EU-15. Natomiast poziom kredytów mieszkaniowych, pomimo niewielkiego zmniejszenia luki, pozostał znacznie niższy. W krajach o wysokim poziomie nasycenia gospodarki kredytami bankowymi (EU-15 oraz NT-2) szybsza dynamika wzrostu cechowała kredyty dla przedsiębiorstw. W latach 2004-2008 nastąpiło zatem stopniowe zawężenie zróżnicowania podmiotowej struktury kredytów pomiędzy wyróżnionymi grupami z 27 do 16 punktów procentowych (rys. 3a).

W 2008 r. udział kredytów dla przedsiębiorstw w kredytach ogółem w krajach EU-15 oraz w krajach CE-5 wyrównał się na poziomie 47\%, w pierwszej grupie wzrastając z poziomu $41 \%$, w drugim zaś obniżając się z poziomu $59 \%$. W pozostałych grupach krajów CEE spadek udziału kredytów gospodarczych zatrzymał się w 2007 r. i pozostał na poziomie ok. 53\%. Można też zauważyć, że w mniejszych krajach EU-15 oraz CE-5 udział kredytów gospodarczych był relatywnie większy. Należy jednak pamiętać, że zrównanie udziału kredytów gospodarczych w kredytach ogółem w EU-15 i CE-5 nastąpiło przy bardzo silnym zróżnicowaniu ich poziomu w relacji do PKB (rys. 3b). W krajach EU-15 kredyty dla przedsiębiorstw w latach 2004-2009 wzrosły z 38\% do 51\% PKB, podczas gdy w krajach CE-5 w tym samym okresie z $19 \%$ do $24 \%$. 
Polska na tle wszystkich krajów UE, zarówno starych, jak i nowych krajów członkowskich, wyróżnia się niepokojąco niskim poziomem kredytów gospodarczych. Pomimo iż ich wartość stanowiła w 2004 r. zaledwie 15\% PKB (mniej tylko w Rumunii - 11\%), w całym analizowanym okresie udział kredytów dla przedsiębiorstw w strukturze udzielonych kredytów obniżał się szybciej niż w innych krajach regionu, co zaowocowało wzrostem relacji kredytów gospodarczych do PKB zaledwie o 2 punkty procentowe (Rumunia w tym czasie zwiększyła udział kredytów gospodarczych z $11 \%$ do $20 \%$ PKB).

\section{Kredyty dla przedsiębiorstw w krajach Europy Środkowo- -Wschodniej}

Kraje CEE, jakkolwiek wyraźnie odróżniają się od krajów EU-15 w zakresie trendów na rynku kredytów gospodarczych, nie stanowią wewnętrznie jednorodnej grupy pomimo przejścia podobnej drogi transformacji od gospodarki planowanej do gospodarki rynkowej. Co więcej, różnice między nimi z czasem się pogłębiły.

Transformacja gospodarcza, która dokonała się w ostatnim dziesięcioleciu ubiegłego wieku, spowodowała głębokie i nieodwracalne zmiany ekonomiczno-społeczne w krajach Europy Środkowo-Wschodniej. Jednym z kluczowych elementów tych przemian był dynamiczny rozwój sektora bankowego, niezbędnego do ukształtowania prawidłowych relacji kredytowo-pieniężnych opartych na mechanizmach rynkowych. Aby umożliwić szybką mobilizację kapitału, a także wdrożenie nowoczesnych technologii i procedur, dokonując prywatyzacji sektora finansowego, podjęto decyzję o otwarciu na kapitał zagraniczny. W wyniku tego struktura własnościowa banków w krajach CEE wykazuje obecnie bardzo niski udział kapitału krajowego (wyjątkiem jest Słowenia). Szczególnie silne zaangażowanie w tym rejonie, zarówno pod względem wartości kontrolowanych aktywów, jak i dywersyfikacji w regionie, przejawia kilka zachodnioeuropejskich grup bankowych, głównie z Włoch (Unicredit, Intesa SanPaolo), Austrii (Raiffeisen, Erste), Belgii (KBC) i Francji (Société Générale) ${ }^{2}$. Kraje CEE po trudnym pierwszym dziesięcioleciu przemian, w którym wiele z nich doświadczyło kryzysu bankowego o różnej skali natężenia, z początkiem XXI w. weszły na ścieżkę szybkiego wzrostu gospodarczego, finansowanego w coraz większym stopniu przez dynamicznie wzrastające kredyty bankowe. Niski poziom nasycenia gospodarki kredytami bankowymi dawał bankom działającym w regionie CEE możliwość uzyskania kilkakrotnie szybszego tempa wzrostu kredytów niż w krajach Europy

${ }^{2}$ Rolę, jaką wymienione grupy bankowe odgrywają w regionie CEE, oraz ocenę efektywności ich działania na tle innych banków w tym regionie przedstawiono w pracy [Mikołajczyk 2014]. 
Zachodniej, co przekładało się też na wyższą rentowność kapitałów zainwestowanych w CEE. Międzynarodowe grupy bankowe gwałtowny wzrost kredytów, przekraczający tempo wzrostu depozytów, finansowały kapitałami wewnętrznymi grupy, pochodzącymi od spółki matki i z rynków zagranicznych [De Haas i van Lelyveld 2010]. Były to jednak w dużym stopniu kredyty niegospodarcze, przeznaczone dla gospodarstw domowych.

Pomimo sprzyjających warunków makroekonomicznych w Polsce wciąż ponad $50 \%$ przedsiębiorstw nie korzysta $\mathrm{z}$ kredytów bankowych na cele inwestycyjne, a odsetek przedsiębiorstw niekorzystających także z kredytów bankowych na działalność bieżącą stanowi 40\% [Sytuacja finansowa... 2014]. Niekorzystanie z kredytów bankowych niekoniecznie musi oznaczać brak dostępu do nich. Może też wynikać z świadomej decyzji przedsiębiorstw o zastosowaniu alternatywnych źródeł finansowania (co czasem oznacza pośrednie finansowanie z krajowych banków zaangażowanych kapitałowo w spółki faktoringowe, leasingowe i inne niebankowe podmioty sektora finansowego) bądź finansowaniu działalności wyłącznie z kapitałów własnych. Odrzucenie korzyści wynikających z zastosowania dźwigni finansowej przez całkowite wyeliminowanie długu (lub silną jego redukcję) przez przedsiębiorstwa nie jest zjawiskiem ani nowym, ani unikalnym. I.A. Strebulaev i B. Yang [2013], badając amerykańskie spółki giełdowe w okresie ponad 50 lat, ocenili, że ponad $10 \%$ z nich nie korzystało z dźwigni finansowej, a kolejne $22 \%$ utrzymywało wskaźnik długu na poziomie nieprzekraczającym $5 \%$. Taka struktura finansowania nie była wynikiem barier w dostępie do kapitału obcego, bo przedsiębiorstwa te charakteryzowały się ponadprzeciętną rentownością, płaciły wyższe dywidendy i utrzymywały wyższą płynność od swoich zadłużonych odpowiedników (podobna wielkość i branża). W Polsce podobnie jak i innych krajach CEE, należących raczej do obszaru rynków wschodzących niż dojrzałych, finansowanie działalności wyłącznie z kapitałów własnych, uzupełnianych głównie kredytem handlowym w rozliczeniach z partnerami, jest jednak w większym stopniu wynikiem istniejących barier w dostępie do bankowych kredytów gospodarczych niż przyjętą strategią finansową. Ekonometryczna analiza ograniczeń kredytowych w regionie Europy Południowo-Wschodniej wskazała na zaburzenia mechanizmów rynkowych, nieefektywność banków oraz asymetrię informacji jako główne przyczyny niedostępności kredytów bankowych dla wiarygodnych przedsiębiorstw, szczególnie w sektorze małych i średnich przedsiębiorstw (odrzucenie wniosku kredytowego lub nieubieganie się o kredyt pomimo zapotrzebowania na kapitał obcy ze względu na zbyt wysokie koszty kredytu i wymagania dotyczące zabezpieczeń) [Money, Banking... 2010]. Globalny kryzys finansowy, a szczególnie będący jego konsekwencją proces delewarowania dużych banków europejskich mocno zaangażowanych w rejonie CEE, stanowił dodatkowy czynnik zagrażający nasileniem trudności w dostępie przed- 
siębiorstw do kredytu bankowego. Zjawisko to potwierdzili we wczesnej fazie kryzysu (2008 r.) dla całego regionu CEE (14 krajów) A. Popov i G.F. Udell [2010], ale w późniejszych latach ograniczenie dynamiki kredytów dla przedsiębiorstw następowało w rejonie w sposób bardzo zróżnicowany (rys. 5). Szczególnie silna redukcja kredytów dla przedsiębiorstw miała miejsce na Węgrzech, w Słowenii i w Europie Południowo-Wschodniej [CEE Banking... 2013].

Z danych na koniec 2012 r. wynika, że polskie przedsiębiorstwa finansują swoją działalność z kredytów i pożyczek krajowego sektora bankowego zaledwie w 12\%, czyli w mniejszym stopniu niż z kredytów handlowych (15\%) czy źródeł alternatywnych (16\%) [Raport o sytuacji... 2014]. Wśród źródeł alternatywnych znajdują się kredyty zagraniczne, które stanowiły ok. 17\% kredytów bankowych zaciągniętych przez polskie przedsiębiorstwa, w największym stopniu korzystały z nich jednak przedsiębiorstwa z udziałem kapitału zagranicznego [Rozwój systemu... 2014]. Niska zależność polskich przedsiębiorstw od kredytu bankowego może być także postrzegana jako element pozytywny - powód większej odporności polskiej gospodarki na skutki kryzysu finansowego [Boguszewski i Lisowska 2012].

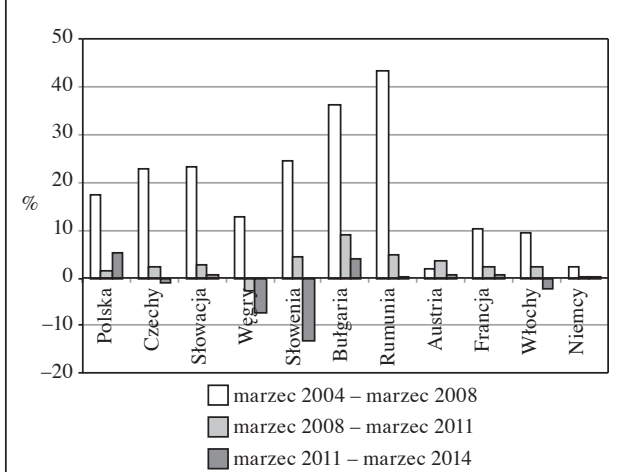

a) kredyty dla przedsiębiorstw

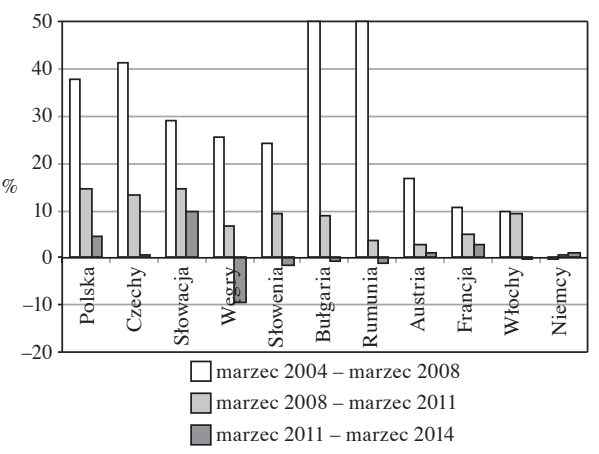

b) kredyty dla gospodarstw domowych

Rys. 5. Średnioroczna stopa wzrostu kredytów w wybranych krajach CEE (CE-5 i SE-2) oraz w głównych krajach pochodzenia kapitału w bankach tego regionu (w \%) Źródło: baza danych ECB, http://sdw.ecb.europa.eu (dostęp: 21.05.2014).

Ze względu na silne zróżnicowanie badany okres został podzielony na trzy podokresy: 2004-2007 (okres boomu kredytowego), 2008-2010 (okres kryzysu) oraz 2011-2013 (okres dostosowań pokryzysowych), a zakres geograficzny ograniczony do siedmiu państw (CE-5 i SE-2). Kształtowanie się główniej zmiennej analizowanej w niniejszym artykule, tj. udziału kredytów dla przedsiębiorstw w kredytach ogółem, przedstawiono dla wybranych krajów na rys. 6 . 


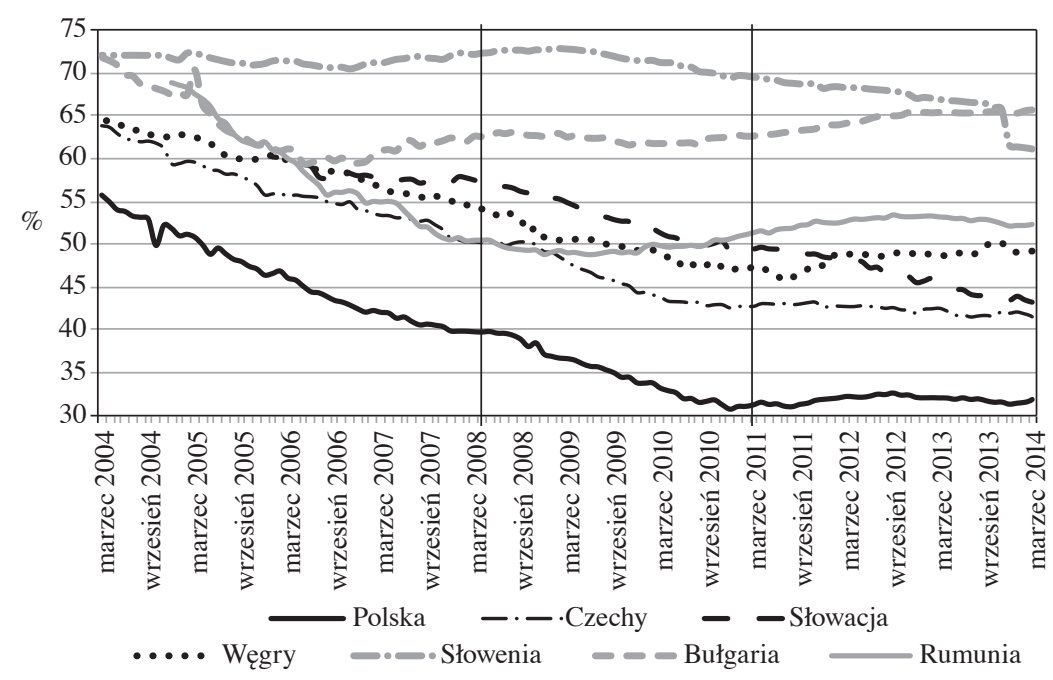

Rys. 6. Udział kredytów dla przedsiębiorstw w kredytach ogółem w krajach CE-5 i SE-2 (w \%)

Źródło: baza danych ECB, http://sdw.ecb.europa.eu (dostęp: 21.05.2014).

Pojawia się pytanie, jakie czynniki i w jakim stopniu wpływały na skłonność banków do udzielania kredytów dla przedsiębiorstw: czy były to czynniki makroekonomiczne, czy raczej strategia banku oraz przynależność do określonej grupy bankowej.

Aby odpowiedzieć na to pytanie, zbudowano model, w którym jako zmienną objaśnianą przyjęto udział kredytów dla przedsiębiorstw w kredytach ogółem w poszczególnych bankach ( $\left.K r P \_K r\right)$, a w roli zmiennych objaśniających wykorzystano zarówno zmienne makroekonomiczne, jak również zmienne opisujące profil i model biznesowy banku oraz przynależność do określonej międzynarodowej grupy bankowej.

$$
K r P_{-} K r=\alpha_{0}+\alpha_{1} X_{1}+\alpha_{2} X_{2}++\alpha_{3} X_{3}+\varepsilon,
$$

gdzie:

$\alpha_{0}-$ wyraz wolny,

$X_{1}$ - macierz zmiennych makroekonomicznych,

$X_{2}$ - macierz zmiennych bankowych,

$X_{3}$ - macierz zmiennych sztucznych wskazujących na przynależność do określonej grupy bankowej, 
$\alpha_{1}, \alpha_{2}$ i $\alpha_{3}$ - macierze parametrów zmiennych odpowiednio makroekonomicznych, bankowych oraz zero-jedynkowych,

$\varepsilon-$ składnik losowy.

Dane jednostkowe o bankach pozyskano z bazy danych Bankscope. Niestety, informacja o strukturze kredytów w wielu przypadkach była niedostępna, co znacznie ograniczyło liczbę banków, jaka mogła zostać przyjęta do analizy. Ponadto dane jednostkowe w bazie Bankscope dostępne były dopiero od $2007 \mathrm{r}$. (a w 2013 r. tylko częściowo uzupełnione). W efekcie analizie poddano okres 2007-2013, podzielony na trzy podokresy, z których pierwszy ograniczono do zaledwie jednego roku (2007). Z pierwotnej liczby 196 banków (banki komercyjne z krajów CE-5 i SE-2) pozostały 102 banki, dla których przynajmniej w jednym roku posiadano informację o wartości kredytów udzielonych przedsiębiorstwom. Opis wykorzystanych zmiennych objaśniających przedstawiono w tabeli 1.

Tabela 1.Zmienne objaśniające wykorzystane w regresji

\begin{tabular}{|c|c|c|c|}
\hline $\begin{array}{l}\text { Zmienne objaśniające } \\
\text { w modelach }\end{array}$ & Symbol & Opis & Źródło \\
\hline \multicolumn{4}{|c|}{ Zmienne makroekonomiczne } \\
\hline Realna stopa wzrostu PKB & $\triangle P K B$ & Tempo wzrostu gospodarczego & Eurostat \\
\hline Kredyty ogółem/PKB & $K r_{-} P K B$ & $\begin{array}{l}\text { Stopień nasycenia gospodarki } \\
\text { kredytami bankowymi }\end{array}$ & ECB, Eurostat \\
\hline $\begin{array}{l}\text { Stopa oprocentowania kredytów } \\
\text { dla przedsiębiorstw }\end{array}$ & $\mathrm{KrP \%}$ & $\begin{array}{l}\text { Koszt kredytu bankowego } \\
\text { dla przedsiębiorstw }\end{array}$ & ECB \\
\hline $\begin{array}{l}\text { Udział 5-ciu największych } \\
\text { banków w aktywach sektora }\end{array}$ & C5 & $\begin{array}{l}\text { Koncentracja sektora bankowego } \\
\text { (zaburzenia konkurencyjności) }\end{array}$ & ECB \\
\hline \multicolumn{4}{|c|}{ Zmienne bankowe } \\
\hline Ln (aktywa) & $\ln (A)$ & $\begin{array}{l}\text { Skala działalności mierzona } \\
\text { wartością aktywów }\end{array}$ & Bankscope \\
\hline $\begin{array}{l}\text { Udział kredytów ogółem w sumie } \\
\text { bilansowej }\end{array}$ & $K r_{-} A$ & Profil inwestycyjny banku & Bankscope \\
\hline $\begin{array}{l}\text { Relacja kredytów do depozytów } \\
\text { od klientów }\end{array}$ & Kr_Dep & $\begin{array}{l}\text { Sposób finansowania działalno- } \\
\text { ści kredytowej (stopień pokrycia } \\
\text { udzielonych kredytów pozyska- } \\
\text { nymi od klientów depozytami) }\end{array}$ & Bankscope \\
\hline Wskaźnik cost to income & $C_{-} I$ & Efektywność kosztowa banku & Bankscope \\
\hline $\begin{array}{l}\text { Relacja kapitałów własnych do } \\
\text { aktywów }\end{array}$ & Kap_A & Stopień kapitalizacji w banku & Bankscope \\
\hline
\end{tabular}


cd. tabeli 1

\begin{tabular}{|c|c|c|c|}
\hline $\begin{array}{c}\text { Zmienne objaśniające } \\
\text { w modelach }\end{array}$ & Symbol & Opis & Źródło \\
\hline \multicolumn{4}{|c|}{ Zmienne zero-jedynkowe } \\
\hline $\begin{array}{l}\text { Zmienne wskazujące na przy- } \\
\text { należność do określonej grupy } \\
\text { bankowej }\end{array}$ & $\begin{array}{l}\text { UNI } \\
\text { RAIF } \\
\text { ERSTE } \\
\text { SG } \\
I S P \\
\text { KBC }\end{array}$ & $\begin{array}{l}\text { Przynależność odpowiednio } \\
\text { do: Unicredit, Raiffeisen, Erste } \\
\text { Group, Société Générale, Intesa } \\
\text { Sanpaolo i KBC }\end{array}$ & $\begin{array}{l}\text { Klasyfikacja } \\
\text { na podstawie } \\
\text { informacji } \\
\text { o strukturze } \\
\text { własnościowej } \\
\text { banków }\end{array}$ \\
\hline
\end{tabular}

Źródło: opracowanie własne.

Spośród zmiennych makroekonomicznych dodatniej relacji ze zmienną objaśnianą oczekiwano dla zmiennej $K r_{-} P K B$ (im wyższe nasycenie kredytami ogółem, tym większy udział kredytów dla przedsiębiorstw w kredytach ogółem), ujemnej dla wskaźnika koncentracji C5 (zbyt silna koncentracja może ograniczać konkurencyjność rynku bankowego i zaburzać mechanizmy rynkowe), natomiast w przypadku dwóch pozostałych zmiennych sposób powiązania jest niejednoznaczny. Wyższe stopy oprocentowania kredytów dla przedsiębiorstw powinny z jednej strony zachęcać banki do zwiększania podaży tych kredytów, z drugiej jednak - jeżeli towarzyszą im relatywnie silniejsze wzrosty stóp oprocentowania kredytów niegospodarczych - relacja może mieć charakter odwrotny. Podobnie jest z tempem wzrostu gospodarczego: wzrost gospodarczy jest czynnikiem zwiększającym popyt na kredyt ze strony przedsiębiorstw, ale zwiększa się też popyt na kredyty wykazywany przez gospodarstwa domowe, co w konsekwencji może ograniczyć udział kredytów gospodarczych w strukturze kredytów ogółem. Spośród zmiennych bankowych pozytywnego znaku oczekiwać można przy zmiennej opisującej relację kredytów do depozytów oraz kapitału własnego do sumy bilansowej (dostęp do lokalnych depozytów oraz silna kapitalizacja banku umożliwiają stabilny rozwój akcji kredytowej). Pozostałe zmienne powinny mieć relację negatywną (banki o silnej pozycji rynkowej mogą maksymalizować bardziej opłacalne kredyty dla gospodarstw domowych kosztem kredytów gospodarczych; wysokie koszty działania banku wymagają podjęcia działań restrukturyzacyjnych).

W tabeli 2 przedstawiono wyniki panelowego modelu regresji z efektami losowymi (model A i B) oraz z efektami stałymi. Test Hausmana wskazuje przewage modelu z efektami stałymi, przedstawiono jednak także wyniki dla modelu z efektami losowymi, gdyż pozwala on wprowadzić dane o przynależności do grupy bankowej (dane niezmienne w czasie). W modelu panelowym z efektami losowymi przynależność do grupy bankowej okazała się jednak nieistotna statystycznie. Spośród zmiennych makroekonomicznych istotny wpływ na udział kredytów dla przedsiębiorstw w portfelu kredytów banku miały wzrost gospodarczy, stopa 
oprocentowania kredytów oraz wskaźnik $C 5$ (we wszystkich przypadkach wpływ pozytywny). Spośród zmiennych bankowych istotne okazały się wielkość banku, relacja kredytów do depozytów oraz relacja kapitału własnego do sumy bilansowej. W modelu z efektami stałymi statystyczną istotność utrzymały tylko dwie zmienne makroekonomiczne: oprocentowanie kredytów oraz wskaźnik koncentracji C5.

Tabela 2. Oceny parametrów dla modelu panelowego (zmienna objaśniana: udział kredytów dla przedsiębiorstw w kredytach ogółem)

\begin{tabular}{|l|c|c|c|}
\hline Zmienne objaśniające & Model A & Model B & Model C \\
\hline Stała & $0,692^{* *}$ & $0,747^{* *}$ & 0,170 \\
\hline$\Delta P K B$ & $0,002^{*}$ & $0,002^{*}$ & 0,001 \\
\hline Kr_PKB & 0,119 & 0,136 & $-0,110$ \\
\hline KrP\% & $0,013^{* *}$ & $0,013^{* *}$ & $0,015^{* *}$ \\
\hline C5 & $0,512^{* *}$ & $0,460^{* *}$ & $0,617^{* *}$ \\
\hline $\ln (A)$ & $-0,033^{* *}$ & $-0,036^{* *}$ & 0,002 \\
\hline Kr_A & $-0,001$ & $-0,001$ & 0,000 \\
\hline Kr_Dep & $0,011^{* *}$ & $0,011^{* *}$ & 0,006 \\
\hline$C_{-} I$ & 0,000 & 0,000 & 0,000 \\
\hline Kap_A & $-0,002^{*}$ & $-0,002^{*}$ & $-0,002$ \\
\hline$U N I$ & 0,105 & - & - \\
\hline RAIF & 0,040 & - & - \\
\hline$E R S T E$ & $-0,164$ & - & - \\
\hline$S G$ & 0,024 & - & - \\
\hline$I S P$ & 0,084 & - & - \\
\hline$K B C$ & $-0,169$ & - & 0,924 \\
\hline$R{ }^{2}$ & 0,113 & 0,102 & 493 \\
\hline$n$ & 493 & 493 & - \\
\hline
\end{tabular}

Uwaga: modele A i B są modelami z efektami losowymi, model C to model z efektami stałymi **, * oznaczają odpowiednio 5- i 10-procentowy poziom istotności.

Źródło: opracowanie własne.

Ponieważ analizowany okres 2007-2013 jest bardzo niejednorodny i wszelkie relacje mają bardzo niestabilny charakter, dokonano także regresji w trzech podokresach reprezentujących: okres boomu kredytowego (tylko jeden rok - 2007), okres zaburzeń kryzysowych na rynkach finansowych (2008-2010) oraz okres dostosowań pokryzysowych (2011-2013). Dla każdego podokresu oszacowano model ze zmiennymi sztucznymi, wskazującymi na przynależność do grupy bankowej, oraz z ich pominięciem. Wyniki przedstawiono w tabeli 3. 
Tabela 3. Wyniki estymacji parametrów dla modeli regresji w trzech podokresach

\begin{tabular}{|c|c|c|c|c|c|c|}
\hline \multirow{2}{*}{$\begin{array}{c}\text { Zmienne } \\
\text { objaśniające }\end{array}$} & \multicolumn{3}{|c|}{ Model ze zmiennymi sztucznymi } & \multicolumn{3}{|c|}{$\begin{array}{l}\text { Model z pominięciem zmiennych } \\
\text { sztucznych }\end{array}$} \\
\hline & 2007 & 2008-2010 & 2011-2013 & 2007 & 2008-2010 & 2011-2013 \\
\hline C & $2,570 * *$ & $1,978 * *$ & 0,163 & $2,380 * *$ & $1,802 * *$ & 0,090 \\
\hline$\triangle P K B$ & $-0,026 *$ & 0,001 & 0,002 & $-0,024 *$ & 0,001 & 0,002 \\
\hline$K r_{-} P K B$ & $-0,008$ & 0,174 & $0,776 * *$ & 0,044 & $0,188 *$ & $0,818 * *$ \\
\hline$K r P \%$ & $-0,031 * *$ & $-0,012 * *$ & 0,009 & $-0,029 * *$ & $-0,011 * *$ & 0,012 \\
\hline$C 5$ & 0,299 & $-0,079$ & 0,341 & 0,360 & 0,030 & 0,316 \\
\hline $\ln (A)$ & $-0,097 * *$ & $-0,082 * *$ & $-0,008$ & $-0,090 * *$ & $-0,077 * *$ & $-0,010$ \\
\hline$K r_{-} A$ & $-0,004 * *$ & $-0,002 *$ & $-0,004 * *$ & $-0,004 * *$ & $-0,001$ & $-0,003 * *$ \\
\hline Kr_Dep & $0,028 *$ & $0,012 * *$ & $0,026 * *$ & $0,026 *$ & $0,011 * *$ & $0,025 * *$ \\
\hline$C_{-} I$ & $-0,001$ & $-0,001$ & 0,000 & $-0,001$ & $-0,001$ & 0,000 \\
\hline Kap_A & 0,000 & 0,002 & 0,001 & $-0,001$ & 0,003 & 0,002 \\
\hline$U N I$ & 0,116 & 0,102 & 0,084 & - & - & - \\
\hline RAIF & 0,107 & 0,111 & 0,067 & - & - & - \\
\hline ERSTE & $-0,010$ & $-0,046$ & $-0,134 *$ & - & - & - \\
\hline$S G$ & 0,060 & 0,081 & $-0,013$ & - & - & - \\
\hline$I S P$ & $0,153 *$ & $0,134 * *$ & $0,129 *$ & - & - & - \\
\hline$K B C$ & 0,004 & 0,026 & $-0,127$ & - & - & - \\
\hline$R^{2}$ & 0,578 & 0,369 & 0,300 & 0,536 & 0,342 & 0,259 \\
\hline
\end{tabular}

Uwaga: **, * oznaczają odpowiednio 5- i 10-procentowy poziom istotności.

Źródło: opracowanie własne.

Analiza w podokresach wykazała zmienny wpływ różnych czynników, szczególnie makroekonomicznych, w zależności od uwarunkowań zewnętrznych. Tempo wzrostu gospodarczego w sposób istotny wpływało na strukturę kredytów tylko w 2007 r. (wyższa stopa wzrostu PKB sprzyjała większemu udziałowi kredytów dla gospodarstw domowych), a poziom nasycenia gospodarki kredytami stał się statystycznie istotny w okresie pokryzysowym (dodatnia relacja z udziałem kredytów gospodarczych). Inaczej niż w modelach panelowych, do 2010 r. odnotowano ujemną zależność stopy oprocentowania kredytów dla przedsiębiorstw z udziałem tych kredytów; w ostatnim okresie znak uległ zmianie, ale też parametr stracił statystyczną istotność na założonym poziomie istotności. Statystyczną istotność stracił też wskaźnik koncentracji C5. Natomiast w obszarze zmiennych bankowych ujemną relację zaobserwowano pomiędzy zmienną objaśnianą a wielkością banku i jego zaangażowaniem w działalność kredytową. Wynika 
z tego, że większą skłonność do udzielania kredytów przedsiębiorstwom miały mniejsze banki oraz banki o bardziej zdywersyfikowanej strukturze aktywów. Czynnikiem sprzyjającym wyższemu udziałowi kredytów dla przedsiębiorstw był wyższy stopień finansowania działalności kredytowej ze źródeł depozytowych. Natomiast przynależność do grupy bankowej nie okazała się istotnym czynnikiem determinującym stopień zaangażowania w kredytowanie przedsiębiorstw. Jedyną grupą bankową statystycznie różniącą się od innych banków wyższym udziałem kredytów gospodarczych w strukturze kredytów była włoska grupa bankowa Intesa SanPaolo.

\section{Podsumowanie}

Analiza czynników wpływających w krajach CEE na strukturę kredytów udzielanych przez banki (stopień ich zaangażowania w finansowanie przedsiębiorstw) pozwoliła na weryfikację postawionej hipotezy badawczej, że czynniki te w dużym stopniu miały charakter makroekonomiczny, a w niewielkim stopniu wynikały z przynależności do określonej grupy bankowej. Wpływ zmiennych makroekonomicznych w analizowanym okresie był jednak bardzo niestabilny, stąd konieczność podziału okresu badawczego na trzy względnie jednorodne podokresy (boom kredytowy, kryzys finansowy, dostosowania pokryzysowe). Istotny wpływ na udział kredytów dla przedsiębiorstw w kredytach ogółem miały także wielkość banku i jego profil oraz źródła finansowania działalności kredytowej.

\section{Literatura}

Beck T., Büyükkarabacak B., Rioja F., Valev N. [2012], Who Gets the Credit? And Does It Matter? Household vs. Firm Lending across Countries, ,The B.E. Journal of Macroeconomics", vol. 12, nr 1, http://dx.doi.org/10.1515/1935-1690.2262.

Boguszewski P., Lisowska M. [2012], Low Reliance on Credit Among Polish Firms: A Blessing in Disguise at a Time of Financial Crisis?, „Gospodarka Narodowa”, nr 7-8.

Cecchetti S.G., Mohanty M.S., Zampolli F. [2011], The Real Effects of Debt, BIS Working Papers, nr 352.

CEE Banking Sector Report [2013], Raiffeisen Research, May.

De Haas R., Ferreira D., Taci A. [2010], What Determines the Composition of Banks' Loan Portfolios? Evidence from Transition Countries, ,Journal of Banking and Finance", nr 34, http://dx.doi.org/10.1016/j.jbankfin.2009.08.005.

De Haas R., Lelyveld I. van [2010], Internal Capital Markets and Lending by Multinational Bank Subsidiaries, ,Journal of Financial Intermediation”, vol. 19, http://dx.doi. org/10.1016/j.jfi.2009.02.001. 
EU Banking Structures [2010], European Central Bank, Frankfurt.

Mikołajczyk K. [2014], Wpływ wybranej strategii na efektywność międzynarodowych grup bankowych działajacych w krajach Europy Środkowo-Wschodniej, ,Folia Oeconomica Acta Universitatis Lodziensis", nr 1(299), http://dx.doi.org/11089/210.

Money, Banking and Financial Markets in Central and Eastern Europe. 20 Years of Transition [2010], red. R. Matousek, Palgrave Macmillan, Basingstoke.

Popov A., Udell G.F. [2010], Cross-border Banking and the International Transmission of Financial Distress During the Crisis of 2007-2008, ECB Working Paper Series, nr 1203.

Raport o sytuacji banków w 2013 r. [2014], Urząd Komisji Nadzoru Finansowego, Warszawa.

Rozwój systemu finansowego w Polsce w 2012 roku [2014], Narodowy Bank Polski, Warszawa.

Strebulaev I.A., Yang B. [2013], The Mystery of Zero-Leverage Firms, ,,Journal of Financial Economics", nr 109, http://dx.doi.org/10.1016/j.jfineco.2013.02.001.

Sytuacja finansowa sektora przedsiębiorstw w IV kw. 2013 [2014], Narodowy Bank Polski, Warszawa.

\section{Factors Affecting Bank Loans to Non-financial Corporations in Central and Eastern European Countries}

Due largely to financial support from their parent entities, banks in Central and Eastern Europe significantly increased their levels of lending during the pre-crisis period especially in consumer credit and house purchases. Indeed, the growth of bank loans in some countries reached the staggering rate of 50\% per year. Yet at the same time the share of corporate loans in total loans decreased. In Poland, for example, the share fell to approximately $30 \%$. The aim of this paper is to present a comparative analysis of trends in business lending in the countries of Central and Eastern Europe and to identify the factors influencing their diversity. The research examined financial statements produced by the banks in the area to investigate the hypothesis that the different levels of involvement in corporate lending resulted from macroeconomic factors in the host country rather than the strategies adopted at the level of international banking groups. The hypothesis was confirmed.

Keywords: enterprise financing, bank loans, portfolio composition, Central and Eastern Europe. 